\title{
Edinburgh malformation syndrome
}

INSERM

\section{Source}

INSERM. (1999). Orphanet: an online rare disease and orphan drug data base. Edinburgh malformation syndrome. ORPHA:1895

Edinburgh malformation syndrome is a rare, genetic, lethal, multiple congenital anomalies/dysmorphic syndrome characterized by consistently abnormal facial appearance, true or apparent hydrocephalus, motor and cog nitive developmental delay, failure to thrive (feeding difficulties, vomiting, chest infections) and death within a few months of birth. Carp mouth, hairiness of the forehead, neonatal hyperbilirubinemia and advanced bone age may also be associated. There have been no further descriptions in the literature since 1991. 